\title{
Entomofauna and potential pollinators of strawberry crop under semi- hydroponic conditions
}

\author{
Bruna Piovesan ${ }^{1} \mathbb{D}$; Aline C Padilha ${ }^{1} \mathbb{D}$; Marcos Botton ${ }^{2} \mathbb{D}$; Moisés João Zotti ${ }^{1} \mathbb{D}$
}

'Universidade Federal de Pelotas (UFPel), Pelotas-RS, Brasil; bruna-piovesan@hotmail.com; acostapadilha08@gmail.com; moises.zotti@ ufpel.edu.br; ${ }^{2}$ Embrapa Uva e Vinho, Bento Gonçalves-RS, Brasil; marcos.botton@embrapa.br

\begin{abstract}
Strawberry cultivation under semi-hydroponic conditions has increased in the Southern region of Brazil since it facilitates management, besides avoiding weather adversities, pests and diseases. However, protected environment can hamper the access of pollinator insects, essential for crop productivity. This work aimed to know the entomofauna associated with strawberry cultivar Albion cultivated under semi-hydroponic conditions and to identify potential species of native pollinating bees. Insects were captured at different times of the day (9:30 a.m., 12:30 p.m. and 3:30 p.m.) in three commercial crops located in Bento Gonçalves and Farroupilha, Rio Grande do Sul. In each study area, three days of sampling were carried out during January 2017. The flowers were visited by 47 species of insects. Apis mellifera (Hymenoptera: Apidae) was the most abundant, constant, dominant and frequent species. Twelve species of native bees were identified: Tetragonisca fiebrigi, Tetrapedia sp., Trigona spinipes, Schwarziana quadripunctata, Plebeia emerina, P. remota, Bombus pauloensis (Hymenoptera: Apidae), Dialictus sp.1, Dialictus sp.2, Augochloropsis sp.1, Augochloropsis sp.2, and Augochlora sp.1 (Hymenoptera: Halictidae). All these species are potential pollinators of the crop. The native species $T$. fiebrigi, $P$. emerina and $P$. remota present potential for directed pollination of the strawberry under protected cultivation due to abundance and ease of management.
\end{abstract}

Keywords: Fragaria x ananassa, pollination, agriculture, diversity, native bees.

\begin{abstract}
RESUMO
Entomofauna e potenciais polinizadores da cultura do morangueiro em cultivo semi-hidropônico

O cultivo do morangueiro no sistema semi-hidropônico tem aumentado na região Sul do Brasil por facilitar o manejo, além de evitar adversidades climáticas, pragas e doenças. Contudo, nesse sistema, o ambiente protegido pode dificultar o acesso de insetos polinizadores, fundamentais para a produtividade da cultura. Assim, este trabalho teve como objetivo conhecer a entomofauna associada ao morangueiro da cultivar Albion cultivado no sistema semi-hidropônico e identificar potenciais espécies de abelhas nativas polinizadoras. Os insetos foram capturados em diferentes períodos do dia (9h30min, 12h30min e 15h30min) em três cultivos comerciais localizados nos municípios de Bento Gonçalves e Farroupilha, Rio Grande do Sul. Em cada área de estudo foram realizados três dias de amostragens durante janeiro de 2017. As flores foram visitadas por 47 espécies de insetos. Apis mellifera (Hymenoptera: Apidae) foi a espécie mais abundante, constante, dominante e frequente. Doze espécies de abelhas nativas foram identificadas: Tetragonisca fiebrigi, Tetrapedia sp., Trigona spinipes, Schwarziana quadripunctata, Plebeia emerina, P. remota, Bombus pauloensis (Hymenoptera: Apidae), Dialictus sp.1, Dialictus sp.2, Augochloropsis sp.1, Augochloropsis sp.2 e Augochlora sp.1 (Hymenoptera: Halictidae). Todas essas espécies são potenciais polinizadoras da cultura. As espécies nativas $T$. fiebrigi, $P$. emerina e $P$. remota apresentam potencial para polinização dirigida do morangueiro em cultivo protegido devido a abundância e facilidade de manejo.
\end{abstract}

Palavras-chave: Fragaria $x$ ananassa, polinização, agricultura, diversidade, abelhas nativas.

\section{Received on September 19, 2018; accepted on May 28, 2019}

$\mathrm{B}$ elonging to the group of small fruits, strawberry (Fragaria x ananassa) is the most widespread crop in the world, being cultivated in nearly all temperate to tropical climate countries (Galvão, 2014). In Brazil, strawberry cultivation is popular in several regions, most notably in the states of Minas Gerais, Paraná, Rio Grande do Sul, São Paulo, Espírito Santo, Santa Catarina and Distrito Federal. The average productivity is about $30 \mathrm{t} \mathrm{ha}^{-1}$, marked differences between regions, depending on the location and cultivation system adopted can be noticed, though (Antunes et al., 2015).

In the last decades, the use of semihydroponic system in high tunnel greenhouse and genetic breeding of plants represented important technological advances which contribute for expansion of cultivated area (Antunes et al., 2015). Semi- hydroponic system shows as one of the main advantages the ease in performing cultural practices compared to the conventional system, since it consists of benches which support packings with substrates attached to the irrigation system. The development of cultivars indifferent to 
photoperiod (day-neutral) extended the production period, allowing cultivation in places with mild temperatures during flowering $\left(10-20^{\circ} \mathrm{C}\right)$ and all year long (Costa et al., 2014). In Rio Grande do Sul, Serra Gaúcha is an important strawberry producer region, in protected environment, under these photoperiodic conditions, where cultivars Aromas and Albion stand out (Costa et al., 2014).

On strawberry crop, pollination is essential to reach physiological maturity, produce fruits and seeds. Although most cultivars are self-fertile, some show variations on their selfpollination ability (Witter et al., 2014). In many cases stigma becomes receptive before anthers release pollen, favoring cross-pollination (Roselino et al., 2009). Pollinating agents like bees are able to carry pollen among different plants, promoting pollination (Zebrowska, 1998).

However, cultivation under protected environment conditions may be a physical barrier to the action of pollinating insects (Antunes et al., 2007). Insufficient amounts of pollen and lack of individuals to carry it among flowers result in imperfect egg fertilization, which decreases hormone production, especially auxins, which would promote the growth of the receptacle area near the achene (Abrol et al., 2017). These factors contribute to high percentages of fruit deformation and lower yield (Malagodi-Braga, 2002; Witter et al., 2012). Considering the global importance of this fruit and the high investment in its implementation and management, it is essential to take pollination into account. Some studies on species of floral visitors in strawberry were carried out under open field cultivation (Malagodi-Braga, 2002; Albano et al., 2009; Connelly et al., 2015; Abrol et al., 2017), whereas in protected environments, few studies can be found in literature (Antunes et al., 2007; Roselino et al., 2009, Witter et al., 2012).

The aim of this study was to know the entomofauna associated with strawberry flowers cultivated in semihydroponic system in Serra Gaúcha Region and identify potential species of native pollinating bees.

\section{MATERIAL AND METHODS}

\section{Study areas}

The study was carried out in three commercial areas using cultivar Albion: area A in Bento Gonçalves-RS

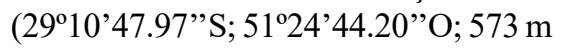
altitude); areas B and C in Farroupilha-

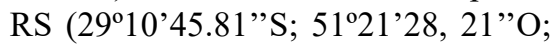
583 m altitude; $29^{\circ} 08^{\prime} 35.37^{\prime \prime} \mathrm{S}$; $51^{\circ} 21^{\prime} 59.82^{\prime} \mathrm{O}$; $565 \mathrm{~m}$ altitude). The local climate is humid temperate, according to Köppen's classification (Moreno, 1961).

The authors used a semi-hydroponic system in the three areas, with strawberry plants grown on benches and in plastic bags with substrate. Nutrient availability was carried out through dripping irrigation system, $12-\mathrm{cm}$ spacing between plants. Cultivation was in a protected environment with plastic cover (in a high tunnel greenhouse, arch type) (30 m length) with open sides. Flowering and fruiting of strawberry was noticed all over the period of this study, since the used cultivar is indifferent to the photoperiod (dayneutral).

Traditional crop managements were kept, such as stolon removal, dry leaves and leaves in excess, application of insecticides and fungicides and fruit harvest. Management of these pesticides was similar in areas A and B; in area $\mathrm{C}$, history of application along the development of the crop showed the adoption of more intense management in relation to the other areas, though. The active ingredients used in area C were: fluazinam, pyrimethanil, azoxystrobin + difeconazole, procimidone, boscalide + cresoximmethyl, abamectin, chlorfenapyr, azadiractin and spinetoram. The occurrence of strawberry borer Lobiopa insularis (Coleoptera: Nitidulidae) and thrips Frankliniella occidentalis (Thysanoptera: Thripidae) resulted in the need for frequent applications of chlorphenapyr and spinetoram in this place. In areas A and B, the following active ingredients were used: fluazinam, iprodione, azoxystrobin + difeconazole, abamectin, azadiractin and chlorfenapyr. In area $\mathrm{A}$, besides these ingredients, the authors also used Bacillus subtilis, for managing Botrytis cinerea (Helotiales: Sclerotiniaceae).

The landscape surrounding the areas was characterized as follows: area $\mathrm{A}=$ existence of small native forest fragments near protected cultivation; area $\mathrm{B}=$ presence of large native forest fragments around cultivation; and area $\mathrm{C}=$ lateral fragment formed by eucalyptus and fruit monocultures (persimmon tree, vine and peach tree).

\section{Sampling of floral visitors}

To collect floral visitors, 25 -meter four transects/cultivation lines were randomly established (adapted from Vaissiéri et al., 2011). Insects were collected directly from flowers with entomological net, totaling three sampling days per area in January 2017. Two previously trained collectors ran each predetermined transect at the same time for fifteen minutes $(7.5 \mathrm{~min}$ round trip), three times along the day (09:30 a.m., 12:30 p.m. and 3:30 p.m.). Soon after collection, insects were stored in falcon tubes $(50 \mathrm{~mL})$ containing cotton moistened with ethyl acetate. In laboratory, insects were sorted, counted, mounted with entomological pins and labeled (Malagodi-Braga, 2002). Specimen identification was performed using a stereomicroscope, with the aid of dichotomous keys and specialists and later deposited in the Ceslau Biesanko Museum entomological collection, belonging to Universidade Federal de Pelotas, Pelotas-RS. The collections were performed on sunny days, with mild winds and temperatures above or equal $15^{\circ} \mathrm{C}$.

\section{Data analysis}

The diversity of insects in the study areas was evaluated by using Hill's diversity profile (1973) using R statistical program. Faunistic analysis was performed to define the abundance, constancy, dominance and frequency classes of bee species, according to described by Silveira Neto et al. (1976).

\section{RESULTS AND DISCUSSION}

A large variety of insects (47 species) was collected visiting strawberry 
Table 1. Number of individuals obtained and their respective collection times observed in areas $A=B e n t o$ Gonçalves-RS, $B$ and $C=$ Farroupilha-RS, 2017. Pelotas, UFPel, 2017.

\begin{tabular}{|c|c|c|c|c|c|c|c|c|c|c|c|c|c|}
\hline \multirow{3}{*}{ Order/family } & \multirow{3}{*}{ Genus/species } & \multicolumn{12}{|c|}{ Collection times/area } \\
\hline & & \multicolumn{3}{|c|}{ 9:30 a.m. } & \multirow{2}{*}{ Total } & \multicolumn{3}{|c|}{ 12:30 p.m. } & \multirow{2}{*}{ Total } & \multicolumn{3}{|c|}{ 3:30 p.m. } & \multirow{2}{*}{ Total } \\
\hline & & $\mathbf{A}$ & $\mathbf{B}$ & $\mathbf{C}$ & & $\mathbf{A}$ & $\mathbf{B}$ & $\mathbf{C}$ & & $\mathbf{A}$ & B & $\mathbf{C}$ & \\
\hline \multicolumn{14}{|l|}{ Hymenoptera } \\
\hline \multirow[t]{8}{*}{ Apidae } & Apis mellifera & 11 & 19 & 33 & 63 & 37 & 39 & 40 & 116 & 21 & 31 & 27 & 79 \\
\hline & Tetragonisca fiebrigi & 6 & $-\ldots$ & - & 6 & 5 & 1 & $-\cdots$ & 6 & 4 & - & - & 4 \\
\hline & Tetrapedia sp. & 1 & - & - & 1 & - & - & - & - & - & - & - & - \\
\hline & Trigona spinipes & 1 & 3 & 1 & 5 & 1 & 1 & 2 & 4 & - & 2 & - & 2 \\
\hline & Schwarziana quadripunctata & 1 & - & - & 1 & - & - & - & - & - & - & - & - \\
\hline & Plebeia emerina & - & 1 & - & 1 & - & 6 & 1 & 7 & - & 1 & - & 1 \\
\hline & Plebeia remota & - & 8 & 1 & 9 & - & - & 1 & 1 & - & 2 & - & 2 \\
\hline & Bombus pauloensis & - & - & 1 & 1 & - & - & - & - & - & - & - & - \\
\hline \multirow[t]{5}{*}{ Halictidae } & Dialictus sp. 1 & 6 & 1 & 1 & 8 & 12 & 5 & 1 & 18 & 2 & 2 & - & 4 \\
\hline & Dialictus sp. 2 & 1 & - & - & 1 & $-\cdots$ & 1 & - & 1 & - & - & - & - \\
\hline & Augochloropsis sp. 1 & 1 & - & - & 1 & - & - & - & - & - & - & - & - \\
\hline & Augochloropsis sp. 2 & - & - & - &.- & - & - & 1 & 1 & - &.- & - & - \\
\hline & Augochlora sp.1 & - & - & 1 & 1 & - & - & - & - & - & - & - & - \\
\hline \multicolumn{14}{|l|}{ Diptera } \\
\hline \multirow[t]{10}{*}{ Syrphidae } & Toxomerus sp. MORFO 1 & 1 & 2 & 1 & 4 & 3 & 10 & - & 13 & 1 & 2 & - & 3 \\
\hline & Toxomerus sp. MORFO 2 & - & - & - & - & - & 1 & - & 1 & - & 1 & 1 & 2 \\
\hline & Toxomerus sp. MORFO 3 & - & - & - & - & - & 1 & 1 & 2 & 1 & - & 1 & 2 \\
\hline & Toxomerus sp. MORFO 4 & - & - & 1 & 1 & - & - & - & - & - & - & - & - \\
\hline & Toxomerus sp. MORFO 5 & - & - & - & - & - & - & 1 & 1 & - & - & - & - \\
\hline & Toxomerus sp. MORFO 6 & - & 1 & - & 1 & - & - & - & - & - & - & - & - \\
\hline & Eristalis sp. MORFO 1 & 3 & - & - & 3 & 1 & - & - & 1 & - & - & 1 & 1 \\
\hline & Eristalis sp. MORFO 2 & - & - & - & - & - & - & - & - & 1 & - & - & 1 \\
\hline & Palpada sp. & 2 & 1 & - & 2 & - & - & - & - & - & - & - & - \\
\hline & Quichuana sp. & - & - & - & - & - & - & - & - & - & - & 1 & 1 \\
\hline \multirow[t]{3}{*}{ Fanniidae } & MORFO 1 & 1 & 1 & - & 2 & - & - & - & - & 1 & 1 & - & 2 \\
\hline & MORFO 2 & - & - & - & - & - & 1 & - & 1 & - & - & - & - \\
\hline & MORFO 4 & - & - & - & - & - & 1 & - & 1 & - & - & - & - \\
\hline \multirow[t]{3}{*}{ Sarcophagidae } & Archytas sp. & - & - & - & - & 1 & - & - & 1 & 1 & 1 & - & 2 \\
\hline & MORFO 1 & - & 1 & - & 1 & - & - & - & - & - & - &.- & - \\
\hline & MORFO 2 & - & - & - & - & - & 1 & - & 1 & - & - & - & - \\
\hline \multirow[t]{2}{*}{ Calliphoridae } & MORFO 1 & - & - & - & - & - & - & - & - & 1 & - & - & 1 \\
\hline & Lucilia sp. & - & - & - & - & - & - & - & - & - & 1 & - & 1 \\
\hline Sepsidae & & - & - & - & - & - & - & - & - & 1 & - & - & 1 \\
\hline Coleoptera & & & & & & & & & & & & & \\
\hline Curculionidae & & 1 & - & - & 1 & - & - & 1 & 1 & - & - & - & - \\
\hline Cantharidae & & - & 1 & - & 1 & 1 & - & - & 1 & 1 & - & - & 1 \\
\hline Chrysomelidae & & $\begin{array}{l}- \\
-\end{array}$ & - & - & - & 1 & - & - & 1 & - & - & - & - \\
\hline & Diabrotica speciosa & - & 9 & 1 & 10 & 1 & 17 & - & 18 & 1 & 8 & - & 9 \\
\hline Coccinellidae & Coleomegilla quadrifasciata & - & - & - & - & - & - & - & - & - & 1 & - & 1 \\
\hline & Eriopis connexa & - & - & - & - & 1 & - & - & 1 & 1 & 3 & - & 4 \\
\hline Tenebrionidae & Lagria villosa & - & 1 & - & 1 & - & - & - & - & - & - & - & - \\
\hline Scarabaeidae & Macraspis dichroa & - & - & - & - & - & - & - & - & - & 1 & - & 1 \\
\hline Hemiptera & & & & & & & & & & & & & \\
\hline Geocoridae & & 1 & - & - & 1 & - & - & - & - & - & - & - & - \\
\hline Miridae & MORFO 1 & 1 & - & - & 1 & - & - & - & - & - & - & - & - \\
\hline & MORFO 2 & - & - & - & - & - & - & - & - & - & 1 & - & 1 \\
\hline Rhyparochromi & & - & - & - & - & - & 1 & - & 1 & - & 1 & - & 1 \\
\hline
\end{tabular}

\section{Lepidoptera}

\begin{tabular}{|c|c|c|c|c|c|c|c|c|c|c|c|c|c|}
\hline Hesperiidae & Hylephila phylaeus phylaeus & - & - & - & - & - & 1 & - & 1 & - & - & - & - \\
\hline & Conga iheringii & - & - & 1 & 1 & - & - & - & - & - & - & - & - \\
\hline Crambidae & Duponchelia fovealis & - & - & 2 & 2 & - & - & - & - & - & - & 1 & 1 \\
\hline Subtotal & & 38 & 49 & 44 & 131 & 64 & 87 & 49 & 200 & 37 & 59 & 32 & 128 \\
\hline
\end{tabular}


flowers (cultivar Albion), including species of orders Hymenoptera, Diptera, Coleoptera, Hemiptera and Lepidoptera (Table 1).

Comparing the study areas (A, B and C) using Hill's analysis, we observed a higher diversity of floral visitants in area $\mathrm{B}$, followed by area $\mathrm{A}$, when compared to area $\mathrm{C}(0=$ species richness; $1=$ Shannon Wiener index; $2=$ Simpson index) (Figure 1). However, regardless of insect diversity, we observed that as equability values were added to the Hill series (to the curve's right), communities ended up behaving similarly (Figure 1 ), which indicates similar species distribution.

Differences in abundance and diversity values may be associated to the management adopted in each area and the inequality between landscapes near the crops. The scarcity of forest fragments and presence of monocultures of fruit trees around area $\mathrm{C}$ may have contributed to these results. According to Ricketts et al. (2008), landscape changes due to intensification of agriculture directly threaten biodiversity. In addition, frequent insecticide applications for strawberry borer and thrips management may have influenced the lower insect diversity in this area. Effects of pesticides on nontarget organisms have been portrayed in several studies (Tomé et al., 2015; PittsSinger \& Barbour, 2016). The presence of larger forest fragments around area B may explain the higher diversity index, as these sites serve as shelter and nesting for various insect species, especially native bees. In area A, despite the existence of small fragments, they were present in larger quantities and closer to the protected cultivation. The surrounding landscape has an effect on the stability of ecosystem services, such as insect pollination (Halinski et al., 2015). Garibaldi et al.

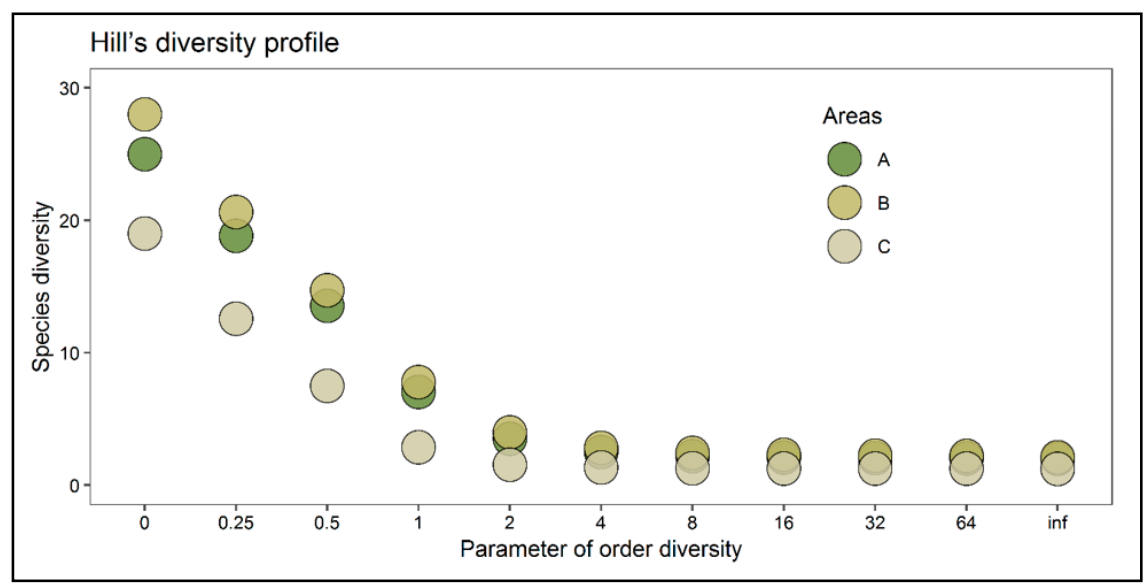

Figure 1. Diversity profile (Hill series) of insects at three sample points (area $A=$ Bento Gonçalves-RS, area B and C: Farroupilha-RS). As it moves to the left of the $x$-axis, greater importance is given to rare species. When moving to the right side rare species become less important, and a greater value to the equability of insect species. Diversity indexes extracted from the $\mathrm{x}$-axis: $0=$ species richness; $1=$ Shannon index; $2=$ Simpson index; Inf $=$ BergerParker index, 2017. Pelotas, UFPel, 2017.

Table 2. Fauna analysis of bee species sampled in three sites with semi-hydroponic strawberry. Pelotas, UFPel, 2017.

\begin{tabular}{|c|c|c|c|c|c|c|c|c|c|c|c|c|}
\hline \multirow{2}{*}{ Genus or species/area } & \multicolumn{4}{|c|}{$\mathbf{A}$} & \multicolumn{4}{|c|}{ B } & \multicolumn{4}{|c|}{ C } \\
\hline & $\mathbf{A}$ & C & D & $\mathbf{F}$ & $\mathbf{A}$ & C & D & $\mathbf{F}$ & A & C & D & $\mathbf{F}$ \\
\hline Apis mellifera & $\mathrm{ma}$ & $\mathrm{w}$ & $\mathrm{d}$ & $\mathrm{mf}$ & $\mathrm{ma}$ & $\overline{\mathrm{w}}$ & $\mathrm{d}$ & $\mathrm{mf}$ & $\mathrm{ma}$ & $\overline{\mathrm{w}}$ & $\bar{d}$ & $\overline{\mathrm{mf}}$ \\
\hline Tetragonisca fiebrigi & ma & $\mathrm{w}$ & d & $\mathrm{mf}$ & $\mathrm{c}$ & $\mathrm{z}$ & nd & $\mathrm{f}$ & - & - & - & - \\
\hline Tetrapedia sp. & $\mathrm{c}$ & $\mathrm{z}$ & nd & $\mathrm{f}$ & - & - & - & - & - & - & - & - \\
\hline Trigona spinipes & $\mathrm{c}$ & $\mathrm{z}$ & nd & $\mathrm{f}$ & $\mathrm{c}$ & $\mathrm{y}$ & $\mathrm{d}$ & $\mathrm{f}$ & $\mathrm{c}$ & $\mathrm{y}$ & $\mathrm{d}$ & $\mathrm{f}$ \\
\hline Schwarziana quadripunctata & $\mathrm{c}$ & $\mathrm{z}$ & nd & $\mathrm{f}$ & - & - & - & - & - & - & - & - \\
\hline Dialictus sp. 1 & ma & $\mathrm{w}$ & $\mathrm{d}$ & $\mathrm{mf}$ & ma & $\mathrm{w}$ & d & $\mathrm{mf}$ & $\mathrm{c}$ & $\mathrm{z}$ & d & $\mathrm{f}$ \\
\hline Dialictus sp. 2 & $\mathrm{c}$ & $\mathrm{z}$ & nd & $\mathrm{f}$ & $\mathrm{c}$ & $\mathrm{z}$ & nd & $\mathrm{f}$ & - & - & - & - \\
\hline Augochloropsis sp.1 & $\mathrm{c}$ & $\mathrm{z}$ & nd & $\mathrm{f}$ & - & - & - & - & - & - & - & - \\
\hline Augochloropsis sp.2 & - & - & - & - & - & - & - & - & $\mathrm{c}$ & $\mathrm{z}$ & nd & $\mathrm{f}$ \\
\hline Plebeia emerina & - & - & - & - & $\mathrm{c}$ & $\mathrm{y}$ & d & $\mathrm{f}$ & $\mathrm{c}$ & $\mathrm{z}$ & nd & $\mathrm{f}$ \\
\hline Plebeia remota & - & - & - & - & $\mathrm{c}$ & $\mathrm{y}$ & $\mathrm{d}$ & $\mathrm{f}$ & $\mathrm{c}$ & $\mathrm{z}$ & $\mathrm{d}$ & $\mathrm{f}$ \\
\hline Augochlora sp.1 & - & - & - & - & - & - & - & - & $\mathrm{c}$ & $\mathrm{z}$ & nd & $\mathrm{f}$ \\
\hline Bombus pauloensis & - & - & - & - & - & - & - & - & $\mathrm{c}$ & $\mathrm{z}$ & nd & $\mathrm{f}$ \\
\hline
\end{tabular}

$\mathrm{A}=$ Abundance: $\mathrm{ma}=$ very abundant; $\mathrm{c}=$ common; $\mathrm{C}=$ Constancy: $\mathrm{w}=$ constant; $\mathrm{y}=$ accessory; $\mathrm{z}=$ accidental; $\mathrm{D}=\mathrm{Dominance}: \mathrm{d}=\mathrm{dominant}$; $\mathrm{nd}=$ non-dominant; $\mathrm{F}=$ Frequency: $\mathrm{mf}=$ very frequent; $\mathrm{f}=$ frequent; - = absent. 


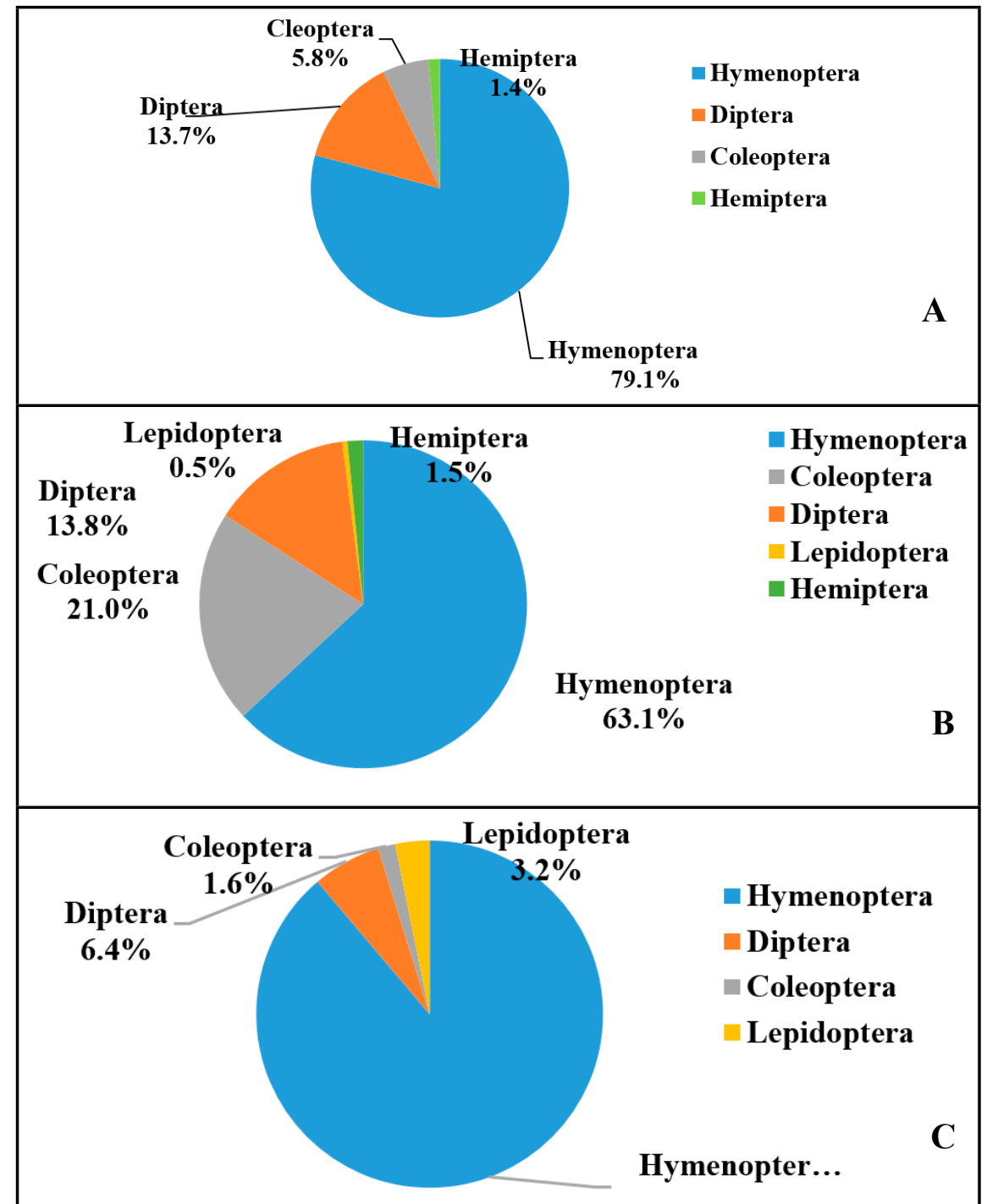

Figure 2. Relative abundance of insect orders collected in strawberry flowers cultivar Albion in the study areas. A= Bento Gonçalves-RS; B and C=Farroupilha, 2017. Pelotas, UFPel, 2017.

three orders was also observed in flowers of 'Campinas' and 'Dover' strawberry cultivated in open system (Malagodi-Braga, 2002). This indicates that even under protected cultivation, as in the case of this greenhouse model adopted in the present study, insects go to the flowers for food resources, and bees, main representatives of the hymenoptera, stand out because they remove nectar and large amounts of pollen to feed the young (MalagodiBraga, 2002).

In relation to species richness, the order Diptera stood out from the rest in areas A and B. In other studies, high richness of Diptera in strawberry flowers of cultivars Chandler and Camarosa was observed (Albano et al., 2009; Abrol et al., 2017). Most collected species of Diptera and Coleoptera are generalist insect predators, which can explain their presence in flowers, as besides prey which may appear, they also feed on pollen, an excellent protein source (Casari \& Ide, 2012). Family Syrphidae (Diptera) was represented by several species, among them the genera Toxomerus, Eristalis, Palpada and Quichuana. In adulthood, these species mimic bees and wasps, feeding almost exclusively on pollen and nectar. During the search for these resources, they end up carrying pollen adhering to their bristles, and may complement the bees in pollinating flowers (Marinoni et al., 2007; Abrol et al., 2017). Other species of families Faniidae, Sarcophagidae, Calliphoridae and Sepsidae (Diptera) are considered only floral visitors, since most grow on decaying organic matter.

Coleoptera of families Curculionidae, Cantharidae, Chrysomelidae (D. speciosa), Tenebrionidae (Lagria villosa) and Scarabaeidae (Macraspis dichroa) were present in the flowers for food. Diabrotica speciosa was observed damaging the reproductive structures of strawberry. Eriopis connexa (Coleoptera: Coccinellidae) and Coleomegilla quadrifasciata (Coleoptera: Coccinellidae) are predators and, just like hemiptera of families Geocoridae and Miridae are present in the environment, playing an important role in biological control of insects-pests. Rhyparochromidae (Hemiptera) and the species Hylephila phylaeus phylaeus, Conga iheringii (Lepidoptera: Hesperiidae), as well as Duponchelia fovealis (Lepidoptera: Crambidae), were considered floral visitors, as they were present only for food and sometimes causing damages to strawberry plants, such as Rhyparochromidae and $D$. fovealis (Bernardi et al., 2015).

Richness of visiting floral species of the order Hymenoptera was similar in all study areas, with eight species in areas $\mathrm{A}$ and $\mathrm{C}$, and seven species in area $\mathrm{B}$, composed of bees belonging to families Apidae and Halictidae (Table 1). The most abundant species was Apis mellifera (Hymenoptera: Apidae), representing $62.7 \%$ of the hymenoptera sampled in area A, $72.4 \%$ in area $\mathrm{B}$ and $90.1 \%$ in area C (Table 1). According to faunal analysis, this species was classified as the most abundant, constant, dominant and very common in all sampled areas (Table 2). Similar results were found in studies evaluating the diversity of insects in cultivars Campinas, Dover and Chandler (Malagodi-Braga, 2002; Abrol et al., 2017). These bees live in colonies with hundreds to thousands of individuals and are easily found due to high foraging activity as they need to collect large amounts of pollen to feed their young (Malagodi-Braga, 2002). They currently represent the main species managed for pollination of agricultural crops worldwide (Rosa et al., 2019).

Besides A. mellifera, several species of native bees were found: 
Trigona spinipes, Tetragonisca fiebrigi, Plebeia emerina, P. remota, Bombus pauloensis, Tetrapedia sp., Schwarziana quadripunctata (Hymenoptera: Apidae), Dialictus sp.1, Dialictus sp.2, Augochlora sp.1, Augochloropsis sp.1, and Augochloropsis sp.2 (Hymenoptera: Halictidae), totalizing 13 species potentially pollinating crop (Table 1 ). In area A, Dialictus sp. 1 and T. fiebrigi were the most abundant $(18.2 \%$ and $13.6 \%$, respectively). In area B, the most abundant native bees were $P$. remota (8.1\%), Dialictus sp.1 (6.5\%) and $P$. emerina (6.5\%), whereas in area $\mathrm{C}$ these bees represent only about $10 \%$ of the collected floral visiting hymenoptera (Tables 1 and 2).

Among native species, T. fiebrigi, $P$. remota and P. emerina are easily found in biomes in the state of Rio Grande do Sul and, in relation to their good adaption to rational management, they show a great potential to use in largescale in protected crops. Tetragonisca angustula and $P$. nigriceps, belonging to the same genera of the species observed in this work, were efficient in pollinating strawberry flowers cultivated in protected environment, reducing mainly the percentage of deformed fruits (Antunes et al., 2007; Witter et al., 2012). Trigona spinipes and $B$. pauloensis were also found, however, some authors report difficulties of managing these pollinating species, since they build their nests in trees and pre-existing cavities, respectively (Marsaro Júnior et al., 2017).

Dialictus sp. 1 was the most abundant native bee in the three areas. Genus Dialictus, as well as genera Augochlora and Augochloropsis, comprise solitary or semi-social bees, known as metallic bees. These bees are easily found pollinating several crops, belonging to the genera with the highest species richness in Southern Brazil (Halinski et al., 2015). Despite the ease of being found in agroecosystems, and the important pollination service they deliver, little is known about their biology, and the fact that they are socially poor makes rational management of pollination difficult. Therefore, it is necessary to adopt conservation measures for these species in their natural habitat, by maintaining forest fragments close to strawberry crops.

The sampling time with the highest abundance and richness of flowervisiting bees was at 12:30 p.m. in all areas (Table 1). The decreased visitation throughout the afternoon may have been influenced by the reduced availability of floral resources. According to Polatto et al. (2014), after a certain period of the day, the scarcity of floral resources produced by most plants can stimulate bees to forage flowers early in subsequent days. Imperatriz-Fonseca et al. (1985) highlight that resource availability is one of external factors which regulate the flight activity of bees.

Higher number of native bees and individuals visited flowers until 12:30 p.m., with declining activities after this period (Table 1). Similar behavior was verified in melon plants (Cucumis melo), where native bees preferred to visit inflorescences in order to collect pollen and nectar during morning time (until 12 p.m.), when temperatures tend to be milder (Tschoeke et al., 2015). The abundance of individuals of species A. mellifera was higher at 12:30 p.m., remaining more active than the other species after 3:30 p.m. (Table 1); according to Chang et al. (2001), their foraging pattern is between 10 and 4 p.m. Tschoeke et al. (2015) verified that $A$. mellifera maintained its activity during afternoon, only to collect nectar, though. Interspecific differences in foraging activities may be directly related to abiotic factors (temperature, luminosity and relative humidity) and the generalist habit of $A$. mellifera, which has populous swarms with a high need for food resources, making it efficient in recruitment of individuals (Giannini et al., 2015).

Knowing some particularities among species may contribute to adopt management strategies for strawberrycrop pollination. One possibility to optimize this ecosystem service is the association of $A$. mellifera, managed in hives near the crops, with native bees, which can be installed inside protected environments and preserved in surrounding forests. The complementary action of different bee species makes the pollination process even more effective, assisting mainly in improving fruit formation (Malagodi-Braga \& Kleinert, 2007).

To simultaneously benefit crop and preserve pollinator species, it is recommended that insecticides and/or fungicides should be applied, when necessary, in the late afternoon, trying to coincide with the lowest pollinator activity times. In addition, the maintenance of native forests around protected cultivations is fundamental for the natural reproduction of the species.

In summary, strawberry cultivation in semi-hydroponic system is visited by a wide entomofauna, including insects of the orders Hymenoptera, Diptera, Coleoptera, Hemiptera and Lepidoptera, being Hymenoptera the most frequent and abundant. The 13 bee species belonging to the Apidae families ( $A$. mellifera, T. fiebrigi, Tetrapedia sp., $T$. spinipes, S. quadripunctata, P. emerina, $P$. remota and $B$. pauloensis) and Halictidae (Dialictus sp.1, Dialictus sp.2, Augochloropsis sp.1, Augochloropsis sp.2, Augochlora sp.1), are potential pollinators of the crop, since they present adaptations for transporting pollen. In the municipalities of Bento Gonçalves and Farroupilha, the introduction of $T$. fiebrigi, $P$. emerina or $P$. remota hives into protected strawberry crops may be an alternative to the pollination deficit due to abundance and easy handling of these species.

\section{ACKNOWLEDGEMENTS}

To Dr. Juliana Galaschi Teixeira (Instituto Tecnológico Vale Belém-PA) and to Dr. Eduardo José Ely e Silva (UFPel/FAEM, Pelotas-RS) for helping identify insects. To Dr. Charles Fernando do Santos (PUC, Porto Alegre-RS) for helping analyze data. To Embrapa Uva e Vinho (Bento Gonçalves-RS) and to Universidade Federal do Rio Grande do Sul (Porto Alegre-RS) to make the entomology laboratories available for identifications. To Coordination of Improvement of Higher Education Personnel (CAPES, Finance Code 001) for granting scholarships. 


\section{REFERENCES}

ABROL, DP; GORKA, AK; ANSARI, MJ; ALGHAMDI, A; AL-KAHTANI, S. 2017. Impact of insect pollinators on yield and fruit quality of strawberry. Saudi Journal of Biological Sciences 1: 1-7.

ALBANO, S; SALVADO, E; BORGES, PAV; MEXIA, A. 2009. Floral visitors, their frequency, activity rate and Index of Visitation Rate in the strawberry fields of Ribatejo, Portugal: selection of potential pollinators. Part 1. Advances in Horticultural Science 23: 238-245.

ANTUNES, LEC; REISSER JUNIOR, C; VIGNOLO, GK; GONÇALVES, MA. 2015. Morangos do jeito que o consumidor gosta. Campo \& Lavoura, Anuário HF 1: 64-72.

ANTUNES, OT; CALVETE, EO; ROCHA, HC; NIENOW, AA; CECCHETTI, D; RIVA, E; MARAN, RE. 2007. Produção de cultivares de morangueiro polinizadas pela abelha jataí em ambiente protegido. Horticultura Brasileira 25: 94-99.

BERNARDI, D; BOTTON, M; NAVA, DE; ZAWADNEAK, MAC. 2015. Guia para a identificação e monitoramento de pragas e seus inimigos naturais em morangueiro. Brasília: Embrapa. 46p.

CASARI, SA; IDE, S. 2012. Coleoptera Linnaeus, 1758. In: RAFAEL, JA; MELO, GAR; CARVALHO, CJB; CASARI, SA; CONSTANTINO, R (eds). Insetos do Brasil: diversidade e taxonomia. Ribeirão Preto: Holos. p.453-535.

CHANG, YD; LEE, MY; MAH, YI. 2001. Pollination on strawberry in the vinyl house by Apis mellifera L. and A. cerana Fab. Acta Horticulturae 561: 257-262.

CONNELLY, H; POVEDA, K; LOEB, G. 2015. Landscape simplification decreases wild bee pollination services to strawberry. Agriculture, Ecosystems and Environment 211: 51-56.

COSTA, RC; CALVETE, EO; MENDONÇA, HFC; DECOSTA, LA. 2014. Phenology and leaf accumulation in vernalized and nonvernalized strawberry seedlings in neutraldays. Acta Scientiarum 36: 57-62.

GALVÃO, AG. 2014. Hibridação de morangueiro e seleção de clones com potencial para cultivo no sul de Minas Gerais. Lavras: UFLA. 77p (Ph.D. thesis).

GARIBALDI, LA; STEFFAN-DEWENTER, I; KREMEN, C; MORALES, JM; BOMMARCO, R; CUN-NINGHAM, AS; CARVALHEIRO, LG; CHACOFF, NP; DUDENHÖFFER, JH; GREENLEAF, SS;
HOLZSCHUH, A; ISAACS, R; KREWENKA, K; MANDELIK, Y; MAYFIELD, MM; MORANDIN, LA; POTTS, SG; RICKETTS, TH; SZENTGYÖRGYI, H; VIANA, BF; WESTPHAL, C; WINFREE, R; KLEIN, AM. 2011. Stability of pollination services decreases with isolation from natural areas despite honey bee visits. Ecology Letters 14: 1062-1072.

GIANNINI, TC; GARIBALDI, LA; ACOSTA, AL; SILVA, JS; MAIA, KP; SARAIVA, AM; GUIMARÃES JUNIOR, PL; KLEINERT, AMP. 2015. Native and non-native supergeneralist bee species have different effects on plant-bee networks. Plos One 10: 1-13.

HALINSKI, R; DORNELES, AL; BLOCHTEIN, B. 2015. Bee assemblage in habitats associated with Brassica napus L. Revista Brasileira de Entomologia 59: 222-228.

HILL, MO. 1973. Diversity and eveness: a unifying notation and its consequences. Ecology 54: 427-432.

IMPERATRIZ-FONSECA, VL; KLEINERTGIOVANNIN, A; PIRES, JT. 1985. Climate variations influence on the flight activity of Plebeia remota Holmberg (Hymenoptera, Apidae, Meliponinae). Revista Brasileira de Entomologia 29: 427-434.

MALAGODI-BRAGA, KS. 2002. Estudo de agentes polinizadores em cultura de morango (Fragaria x ananassa Duchesne- Rosaceae). São Paulo: IB-USP. 104p (Ph.D. thesis).

MALAGODI-BRAGA, KS; KLEINERT, AMP. 2007. Como o comportamento das abelhas na flor do morangueiro (Fragaria ananassa Duchesne) influencia a formação dos frutos? Bioscience Journal 23: 76-81.

MARINONI, L; MORALES, MN; SPALER, I. 2007. Chave de identificação ilustrada para os gêneros de Syrphinae (Diptera, Syrphidae) de ocorrência no sul do Brasil. Biota Neotropica 7: 144-157.

MARSARO JÚNIOR, AL; HALINSKI, R; BLOCHTEIN, B; PEREIRA, PRVS; TOMM, GO; FERREIRA, PEP. 2017. Diversidade de abelhas na cultura da canola no Rio Grande do Sul. Passo Fundo: Embrapa Trigo. 22p. (Documentos online 168).

MORENO, JA. 1961. Clima do Rio Grande do Sul. Porto Alegre: Secretaria da Agricultura, 42p.

PITTS-SINGER, TL; BARBOUR, JD. 2016. Effects of residual novaluron on reproduction in alfalfa leaf cutting bees, Megachile rotundata F. (Megachilidae). Pest Management Science 73: 153-159.

POLATTO, LP; CHAUD-NETTO, J; ALVES-
JUNIOR, VV. 2014. Influence of abiotic factors and floral resource availability on daily foraging activity of bees. Journal of Insect Behavior 27: 593-612.

RICKETTS, TH; REGETZ, J; STEFFANDEWENTER, I; CUNNINGHAM, SA; KREMEN, C; BOGDANSKI, A; GEMMILLHERREN, B; GREENLEAF, SS; KLEIN, AM; MAYFIELD, MM; MORANDIN, LA; OCHIENG, A; VIANA, BF. 2008. Landscape effects on crop pollination services: are there general patterns? Ecology Letters 11: 499-515.

ROSA, JMDA; ARIOLI, CJ; NUNES-SILVA, P; GARCIA, FRM. 2019. Desaparecimento de abelhas polinizadoras nos sistemas naturais e agrícolas: Existe uma explicação? Revista de Ciências Agroveterinárias 18: 154-162.

ROSELINO, AC; SANTOS, SB; HRNCIR, M; BEGO, LR. 2009. Differences between the quality of strawberries (Fragaria x ananassa) pollinated by the stingless bees Scaptotrigona aff. depilis and Nannotrigona testaceicornis. Genetics and Molecular Research 8: 539-545.

SILVEIRANETO, S; NAKANO, O; BARBIN, D; VILA NOVA, NA. 1976. Manual de ecologia de insetos. Piracicaba: Ceres. 419p.

TOMÉ, HVV; BARBOSA, WF; MARTINS, GF; GUEDES, RNC. 2015. Spinosad in the native stingless bee Melipona quadrifasciata: Regrettable non-target toxicity of a bioinsecticide. Chemosphere 124: 103-109.

TSCHOEKE, PH; OLIVEIRA, EE; DALCIN, MS; SILVEIRA-TSCHOEKE, MCAC; SANTOS, GR. 2015. Diversity and flowervisiting rates of bee species as potential pollinators of melon (Cucumis melo L.) in the Brazilian Cerrado. Scientia Horticulturae 186: 207-216.

VAISSIÉRE, BE; FREITAS, BM; GEMMILLHERREN, B. 2011. Protocol to detect and assess pollination deficits in crops: a handbook for its use. Food and Agriculture Organization of the United Nations 1: 1-82.

WITTER, S; RADIN, B; LISBOA, BB; TEIXEIRA, JSG; BLOCTEIN, B; IMPERATRIZ-FONSECA, VL. 2012. Desempenho de cultivares de morango submetidas a diferentes tipos de polinização em cultivo protegido. Pesquisa Agropecuária Brasileira 47: 58-65.

WITTER, S; NUNES-SILVA, P; BLOCHTEIN, B; LISBOA, BB; IMPERATRIZ-FONSECA, VL. 2014. As abelhas e a agricultura. Porto Alegre: EDIPUCRS. 143p.

ZEBROWSKA, J. 1998. Influence of pollination modes on yield componentes in strawberry (Fragaria x ananassa Duch.). Plant Breeding 117: 225-260. 